\title{
Fundamentals of the spatially distributed simulation of the water balance of forest sites in a low-range mountain area
}

\author{
K. Schwärzel ${ }^{1}$, J. Häntzschel ${ }^{1}$, T. Grünwald ${ }^{2}$, B. Köstner ${ }^{2}$, C. Bernhofer ${ }^{2}$, and K.-H. Feger ${ }^{1}$ \\ ${ }^{1}$ Institute of Soil Science and Site Ecology, Dresden University of Technology, Germany \\ ${ }^{2}$ Institute of Hydrology and Meteorology, Dresden University of Technology, Germany
}

Received: 10 January 2007 - Revised: 12 April 2007 - Accepted: 15 May 2007 - Published: 30 May 2007

\begin{abstract}
For a sustainable forest management, a sitespecific knowledge on the water balance is a prerequisite. A simple and popular field method for assessing the water balance of forest sites is based on overlaying relief and soil information. Furthermore, climatic influence on the water balance is often restricted to longtime average values of precipitation and air temperature (whole year and/or growing season). However, the impacts of climate change and climatic extremes, as well as silvicultural changes, are inadequately considered. To overcome these short-comings, we integrated the 1D-SVAT model BROOK90 and a radiation model in a GIS to simulate the spatially distributed components of water balance of forest sites. In this paper, we present the model concept and show an approach to describe the influence of a complex terrain on parameters controlling the spatial distribution of energy and water fluxes.
\end{abstract}

\section{Introduction}

A site-adapted and sustainable management of forest sites requires a spatially differentiated knowledge of the water balance, notably the dynamics of plant-available water pools in the soil. In particular, practitioners are interested in knowing if the water available at the site is sufficient to ensure an optimal stand growth. In the lumped approaches of forest site evaluation in Germany (AK Standortskartierung, 2003), water availability is assessed by overlaying information on climate, relief, and soil. The climatic influence on soil water dynamics is defined by the combined use of long-year average values for precipitation and air temperature (whole year or growing season). The relief describes the influence of topography (at slopes: aspect, length, shape, and gradient) on the distribution of energy and water fluxes. The influence of the soil on the water supply and the water balance is characterized by the water storage capacity of the soil and by the water table effects.

However, the aforementioned approach allows only a qualitative, semi-empiric classification of the water balance of forest sites on the basis of field observations. Such an assessment of the water supply is mostly based on longtime average values which roughly characterize the general growth conditions with respect to climate. Periods of climatic extremes (notably droughts), which have also a high ecological relevance, are normally neglected. Furthermore, the impacts of climate change as well as forest management (e.g. choice of tree species and their mixture, thinning regime) are inadequately considered. To overcome these problems we have started to develop a GIS-based modeling system that enables a spatially distributed prediction of the water balance of forest sites, depending on climate, topography, soil type, and forest stand. Our testing area Tharandter Wald $\left(60 \mathrm{~km}^{2}\right)$ is situated about $25 \mathrm{~km} \mathrm{SW}$ of Dresden (SE Germany). The Tharandter Wald is part of the lower elevations of the E Ore Mountains (Osterzgebirge) and features distinctive variablities in relief, soil type, and vegetation. Since 1996, at different spatial and temporal scales, energy and water fluxes have been measured continuously using the eddy covariance technique, sap flow, and soil water content at two sites stocked with Norway spruce (Picea abies) and common beech (Fagus sylvatica) (Grünwald and Bernhofer, 2007). These measurements are essential for the development and calibration of the modeling system. In this paper we present (i) the concept of the GIS-based modeling system, (ii) a comparison of observed and predicted values of the water balance components of the spruce stand, and (iii) first results of the regionalization of input data of radiation and precipitation.

Correspondence to: K. Schwärzel

(kai.schwaerzel@frsws10.forst.tu-dresden.de)

Published by Copernicus Publications on behalf of the European Geosciences Union. 


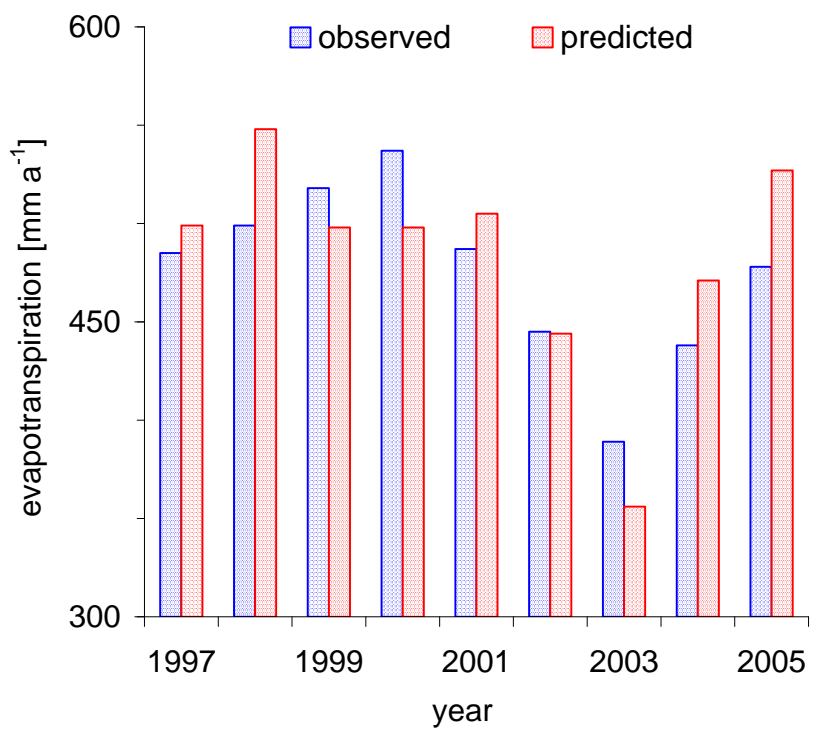

Fig. 1. Observed and predicted annual evapotranspiration for period 1997 - 2005. Tharandter Wald (“Anchor Station”, old spruce stand, loamy skeletal podsol-brown earth/Dystric Cambisol).

\subsection{Modeling concept}

For modeling we use the physically-based soil water model BROOK90 (Federer, 1995). BROOK90 simulates the daily evapotranspiration and the water movement in variably saturated soils, with provision for streamflow generation using different flow paths. The model calculates rates of evaporation (soil and snow), transpiration, and evaporation of intercepted rain and snow. The following meteorological input data are required on a daily basis: precipitation, maximum and minimum temperature, vapor pressure, wind, and solar radiation or sunshine duration. BROOK90 uses the Shuttleworth-Wallace approach (1985) for separating transpiration and soil evaporation from sparse canopies, and for evaporation of interception. In our study we used LWFBROOK90 (Version 3.3), which had been modified by Hammel and Kennel (2001) from the original BROOK90. Compared to the version by Federer (1995), the LWF-BROOK90 allows a description of the soil hydraulic properties using the van Genuchten-Mualem-model (VGM-model; van Genuchten, 1980; Mualem, 1976), the simulation of stand development over the time, and the alteration of LAI during the season using a phenological model (Menzel, 1997; von Wilpert, 1990).

To simulate the spatially distributed water balance the 1D-process-oriented model LWF-BROOK90 was integrated in a GIS environment ArcView. This approach called BROOK90+ includes several routines for formatting, processing and managing information on geography, meteorology, pedology, and land use. Furthermore, it contains modules for the daily calculation of spatially distributed meteo-
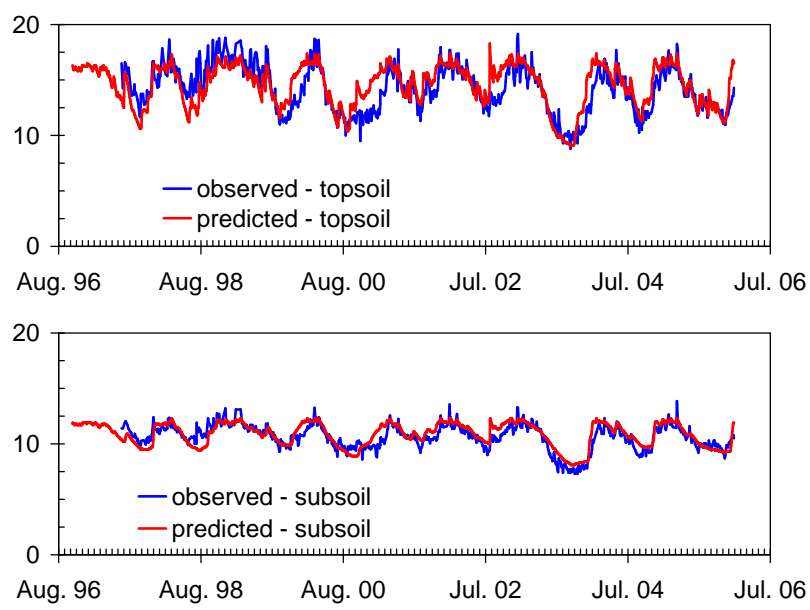

Fig. 2. Observed and predicted soil water contents of the topsoil $(30 \mathrm{~cm})$ and the subsoil $(70 \mathrm{~cm})$. Tharandter Wald ("Anchor Station", old spruce stand, loamy skeletal podsol-brown earth/Dystric Cambisol).

rological input values. For this purpose, the transfer of meteorological data measured at the ground station to the area is based on the digital elevation model (SLVA) of the Land Survey Office of Saxony with a resolution of $25 \mathrm{~m}$. Besides the soil water model LWF-BROOK90, the radiation model GISRAD was integrated in the GIS environment. With GISRAD, short-wave radiation components at an inclined surface can be calculated or adapted from measurements for arbitrary locations and different time steps by a surface related radiation factor (Goldberg and Häntzschel 2002, see Fig. 3). Note that the effects of shading by the surrounding surface or the slope can be also considered (Häntzschel et al., 2005). The regionalization of temperature values are realized by elevation gradients, which are derived from long term measurements of surrounding climate stations. A similar approach is used to calculate the precipitation of the area (see Fig. 4). It considers interactions between inclined slopes and wind direction based on trigonometric functions according to Junghans (1967) and Goldberg (1999). The necessary information of wind direction, wind speed, and vapor pressure is received from climate stations of the study area. Vegetation parameters (stand characteristics such as tree height, tree (canopy) density or the leaf area index) are derived from land-use maps and forest inventory data. For the spatially distributed simulation of the soil water fluxes information on the hydraulic properties of the individual soils (water retention curve, unsaturated hydraulic conductivity) are needed. A viable approach to gather such information may be the analysis of forest soil maps (scale 1:10000) and corresponding soil profile descriptions. A first step is to examine soil texture data in order to aggregate "soil hydrological units" from the multitude of existing soil series as outlined in the forest site map. For these units, the parameters of the water retention curve and 

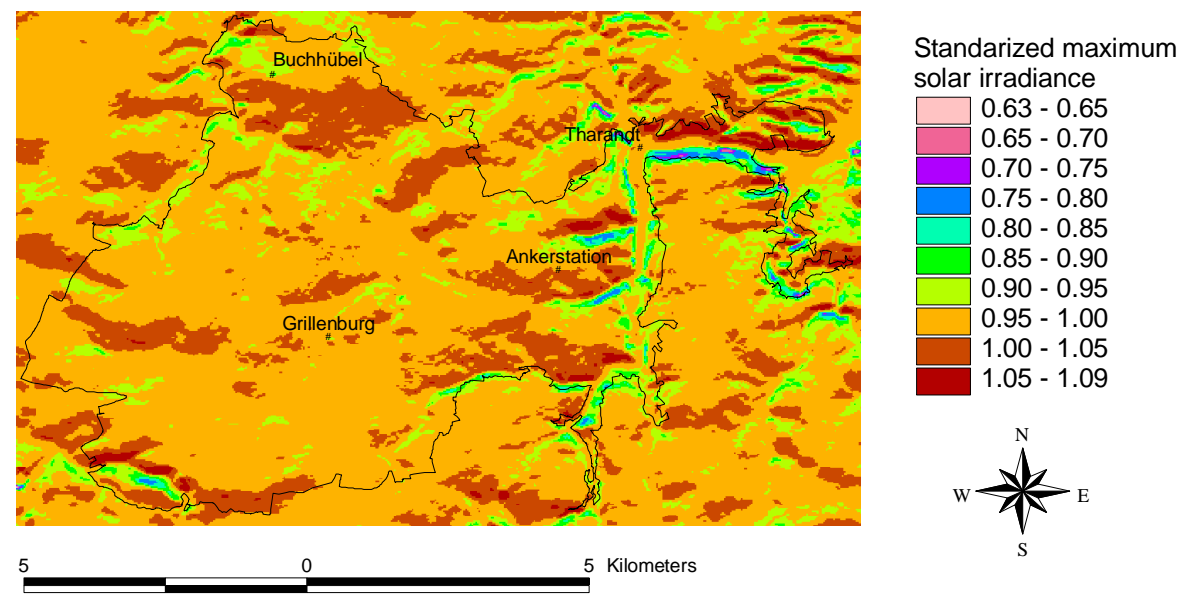

Fig. 3. Maximum solar radiation standardized to the maximum solar radiation measured at the Tharandter Wald "Anchor" station, 21 June.

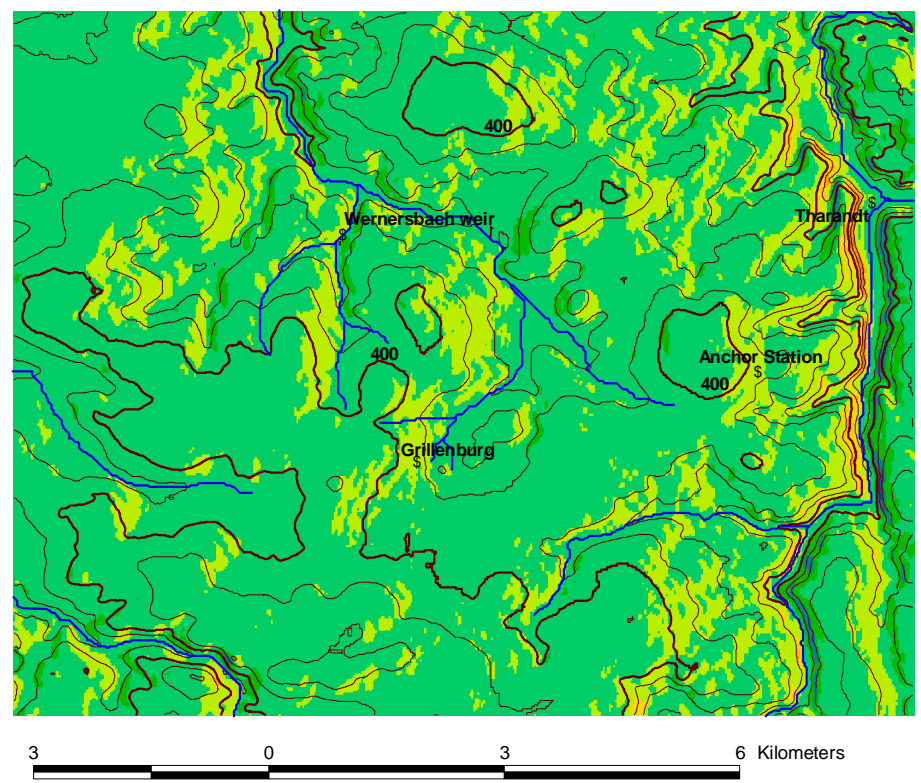

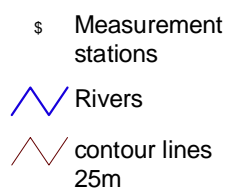

Phyd / Pmet

$0.91-0.93$

$0.93-0.95$

$0.95-0.97$

$0.97-0.99$

$0.99-1.01$

$1.01-1.03$

$1.03-1.05$

$1.05-1.07$

$1.07-1.09$

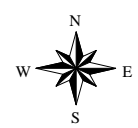

Fig. 4. Ratio of hydrological (Phyd) to meteorological precipitation (Pmet) (annual rates), Tharandter Wald.

the hydraulic conductivity function will be derived by means of pedotransfer functions.

\subsection{Results}

\subsubsection{Calibration of LWF-BROOK90}

Using the LWF-BROOK90 the evapotranspiration and runoff components and changes in the soil water supply were calculated on a daily basis for an old spruce stand for the period 1/11/1996-31/12/2005. The soil at this site is a loamy skeletal podsol-brown earth (WRB: Dystric Cambisol). It can be seen from Fig. 1 that a close agreement between the measurements and the simulations was obtained. The dif- ferences between the observed and predicted annual sums of evapotranspiration were $<10 \%$. During the simulation period, we found a mean evapotranspiration of $475 \mathrm{~mm} \mathrm{yr}^{-1}$; this amount corresponds to $\sim 60 \%$ of the annual precipitation.

LWF-BROOK90 was able to reflect well the observed pattern of a seasonal variation of drying out and being remoistened (Fig. 2). Discrepancies between measured and simulated water contents occur mainly in the winter months. In these months, alternating soil frost and thawing processes, especially in the topsoil, led to extreme fluctuations in the water content which the model was not sufficiently able to reproduce. The low water content in the topsoil could, 
moreover, be due to frost-dependant artifacts in TDR measurements.

\subsection{Regionalization of meteorological data}

For the provision of spatially distributed solar radiation data, the radiation model GISRAD was interfaced with the GIS. This procedure allows for extrapolating data measured at local stations (point information) to a whole target area by using terrain geometry and atmospheric conditions at a given time. This regionalization procedure can be carried out as follows: For each day of the year, at each point of our testing area the ratio between the maximum solar radiation at this location and at the local measurement station was modelled in GISRAD (the spatial resolution depends on the grid space of the digital elevation model). So, for every point and for every day of the year we obtain a factor, which describes the variability in solar radiation due to the terrain geometry in relation to the measurement station. With it, the daily solar irradiance, measured at the "Anchor Station" can be adapted to the surrouding area. Figure 3 shows this ratio (factor) for our testing area on 21 June. The influence of the terrain geometry on the distribution of energy is striking. The south-facing slopes obtain up to $40 \%$ more irradiation than the north-facing slopes. Figure 3 describes the distribution of the solar radiation without considering cloud cover. To take into account the effects of cloud cover on solar radiation it is necessary to multiply the actually measured solar radiation with the aforementioned factors.

The impact of terrain geometry on the distribution of precipitation is shown in Fig. 4. The map exemplifies the factors between the annual values of the hydrological and meteorological precipitation. Notice the meteorological precipitation describes the rate of precipitation measured at a climate station and adapted to the surrounding terrain by a known elevation gradient. The hydrological precipitation additionally takes into account the impact of wind effects (luv/lee) on the meteorological precipitation (Junghans, 1967). The results presented in Fig. 4 are based on orographic gradients and the analysis of long-term distribution of wind direction/precipitation using a 30-yr dataset for various stations in the Ore Mountains (Goldberg, 1999). Rain shadow effects are clearly visible on the east-facing slopes whereas the west-facing slopes of our testing area receive up to $10 \%$ more annual precipitation.

\subsection{Outlook}

Upon completion of BROOK90+, a spatially distributed simulation of the water balance of our testing area will be conducted on the basis of a long-term dataset of atmospheric conditions. Model runs with BROOK90+ will take place in two ways. First, based on the horizontal resolution of the digital elevation data water balance will be simulated for each grid point, to figure out the effects of topography, soil hydro- logical units, and tree species on evapotranspiration and soil water dynamics. Based on these outcomes and in consideration of derived "soil units" an aggregation of new calculation areas with a practicable resolution will follow. The influence of the complex terrain on the water balance components can then be evaluated using spatially distributed stress indicators (e.g. degree of water depletion by the plant roots during the growing season, ratio between actual and potential transpiration, frequency and duration of drought/water logging). This will allow the retrospective analysis of site conditions, e.g. for the interpretation of growth or for the simulation of different practice of forest management. Also, the quantification of water balance components related to a larger area (e.g. groundwater recharge) will be feasible. This ensures an advanced use of forestry data to address hydrological problems.

Acknowledgements. The German Science Foundation DFG (FE540) funded this study. The long-term data records by the group of $\mathrm{Ch}$. Bernhofer were obtained in the frame of the EU funded projects EUROFLUX (ENVCT 0095-0078), CARBOEUROFLUX (ENVK2-1999-00229) and CARBOEUROPE-IP (GOCE-CT2003-505572), as well as the project VERTIKO (AFO2000), funded by the German Ministry of Education and Research (BMBF).

Edited by: K.-E. Lindenschmidt

Reviewed by: A. Blattner and an anonymous referee

\section{References}

AK Standortskartierung 2003: Forstliche Standortsaufnahme, 6th edition, IHW-Verlag, Eching bei München, Germany, 2003.

Federer, C. A.: BROOK90: A simulation model for evaporation, soil water and stream flow, Version 3.1 Computer Freeware and Documentation, USDA Forest Service, PO Box 640, Durham NH 03825, USA, 1995.

Goldberg, V. and Häntzschel, J.: Application of a radiation model for small-scale complex terrain in a GIS environment, Meteorol. Zeitschrift (N.F.), 11, 119-128, 2002.

Goldberg, V.: Zur Regionalisierung des Klimas in den Hochlagen des Osterzgebirges unter Berücksichtigung des Einflusses von Wäldern (in German with English summary), Tharandter Klimaprotokolle 2, Technische Univ. Dresden, 193 S., 1999.

Grünwald, T. and Bernhofer, C.: A decade of flux measurements of an old spruce forest at the Anchor Station Tharandt, Tellus B, Online Early Articles, doi:10.1111/j.1600-0889.2007.00259.x, published article online: 20-Apr-2007.

Hammel, K. and Kennel, M.: Charakterisierung und Analyse der Wasserverfügbarkeit und des Wasserhaushaltes von Waldstandorten in Bayern mit dem Simulationsmodell BROOK90 (in German with English summary), Forstliche Forschungsberichte München, 185, 2001.

Häntzschel, J., Goldberg, V., and Bernhofer, Ch.: GIS based regionalization of radiation, temperature and coupling measures in complex terrain for low mountain ranges, Meteorol. Appl., 148, 33-42, 2005.

Junghans, H.: Der Niederschlag auf geneigte Flächen (in German), Zeitschrift für Angewandte Meteorologie, 5, 222-226, 1967. 
Menzel, A.: Phänologie von Waldbäumen unter sich ändernden Klimabedingungen - Auswertung der Beobachtungen in den internationalen phänologischen Gärten und Möglichkeiten der Modellierung von Phänodaten (in German with English summary), PhD. Diss., Forstliche Forschungsberichte München, 164, 1997.

Mualem, Y.: A new model for predicting the hydraulic conductivity of unsaturated porous media, Water Resour. Res., 12, 513-522, 1976.

Shuttleworth, W. J. and Wallace, J. S.: Evaporation from sparse crops - an energy combination theory, Q. J. Roy. Meteor. Soc., 111, 839-855, 1985.
Van Genuchten, M. Th.: A closed-form equation for predicting the hydraulic conductivity of unsaturated soils, Soil Sci. Soc. Am. J., 44, 892-898, 1980.

Von Wilpert, K.: Die Jahrringstruktur von Fichten in Abhängigkeit von Bodenwasserhaushalt auf Pseudogley und Parabraunerde (in German with English summary), PhD. Diss. Institut für Bodenkunde und Waldernährungslehre der Albert-LudwigsUniversität Freiburg i. Br., 1990. 